\title{
ANALISIS RASIO LIKUIDITAS DAN RASIO PROFITABILITAS PADA PERUSAHAAN DAERAH AIR MINUM KABUPATEN OGAN KOMERING ULU
}

\author{
Yuniarti Anwar \\ Program Studi Manajemen Sekolah Tinggi Ilmu Ekonomi (STIE) Dwi Sakti Baturaja \\ Email: yuniartianwarsemsi@gmail.com \\ Yopi Yunsepa \\ Program Studi Manajemen Sekolah Tinggi Ilmu Ekonomi (STIE) Dwi Sakti Baturaja \\ Email: yopizulhanapi@gmail.com \\ Rafiza Meliyani \\ Program Studi Manajemen Sekolah Tinggi Ilmu Ekonomi (STIE) Dwi Sakti Baturaja \\ Email: rafizameliyani@gmail.com
}

DOI: http://dx.doi.org/10.35908/jeg.v5i1.868

\begin{abstract}
Analysis of Liquidity Ratios and Profitability Ratios in Ogan Komering Ulu District Water Supply Company. The formulation of the problem in this study is how liquidity ratios and profitability ratios in Ogan Komering Ulu Regional Water Supply Company? The purpose of this study was to determine the liquidity ratios and profitability ratios in the Regional Water Supply Company of Ogan Komering Ulu Regency.

Data analysis techniques used in research using qualitative and quantitative analysis with descriptive methods. The type of data used are primary data and secondary data. From the results of the analysis of the calculation of the level of liquidity of the Regional Water Supply Company of Ogan Komering Ulu Regency during 2014-2017, the average value of the quick ratio was 903.5\%, current ratio $1,008.75 \%$ and cash ratio of $58.75 \%$. This shows that the company is in good condition because it has exceeded industry standards where the company is able to fulfill its short-term obligations. And the level of profitability over the past four years, namely 2014-2017, is not in a good condition because the calculation of net profit margin, return on investment, and return on equity has a negative value, this is because the company always loses and has not been able to manage the source of funds owned efficient and effective.
\end{abstract}

Keywords: Analysis of financial ratios, liquidity, profitability

\section{Pendahuluan}

Kinerja perusahaan merupakan suatu gambaran tentang kondisi keuangan suatu perusahaan yang dianalisis dengan alatalat analisis keuangan. Menurut Munawir (2010:31), analisa laporan keuangan terdiri dari pada hubungan-hubungan atau kecenderungan untuk menentukan posisi keuangan dan operasi serta perkembangan usaha yang bersangkutan. Dengan diadakannya analisa laporan keuangan ini diharapkan dapat dihasilkan informasi yang berguna bagi pihak yang berkepentingan. 
Perusahaan Daerah Air Minum (PDAM) merupakan salah satu unit usaha milik daerah yang bergerak dalam distribusi air bersih bagi masyarakat dengan tujuan yaitu tujuan sosial dan ekonomi. Sebuah perusahaan yang didirikan oleh pemerintah daerah yang dapat meningkatkan pendapatan daerah. PDAM sebagai salah satu perusahaan daerah berupaya untuk meningkatkan kinerja keuangannya yang salah satunya bercermin dari tingkat keuntungan yang diperoleh per periode.

Perusahaan Daerah Air Minum Kabupaten Ogan Komering Ulu dalam kondisi keuangannya belum menunjukkan kinerja yang baik karena berdasarkan laporan keuangan PDAM Kabupaten OKU pada tahun 2014-2017 khususnya pada laporan laba rugi menyatakan bahwa PDAM Kabupaten OKU dari tahun ke tahun mengalami kerugian.

Berdasarkan uraian latar belakang tersebut diatas, maka dapat diajukan sebuah penelitian dengan judul ANALISIS RASIO LIKUIDITAS DAN RASIO PROFITABILITAS PADA PERUSAHAAN DAERAH AIR MINUM KABUPATEN OGAN KOMERING ULU.

Rumusan masalah dalam penelitian ini adalah bagaimana rasio likuiditas dan rasio profitabilitas pada Perusahaan Daerah Air Minum Kabupaten Ogan Komering Ulu?

Tujuan dalam penelitian ini adalah untuk mengetahui rasio likuiditas dan rasio profitabilitas pada Perusahaan Daerah Air Minum Kabupaten Ogan Komering Ulu.

\section{Tinjauan Pustaka}

\section{a. Definisi Rasio Keuangan}

Menurut Fahmi (2014:49) rasio keuangan adalah suatu kajian yang melihat perbandingan antara jumlah-jumlah yang terdapat pada laporan keuangan dengan mempergunakan formula-formula yang dianggap reprensentatif untuk digunakan. Rasio keuangan ini hanya menyederhanakan informasi yang menggambarkan antara pos tertentu dengan pos lainnya, dengan penyederhanaan ini kita dapat membandingkan dengan rasio lain sehingga dapat memperoleh informasi dan memberikan penilaian.

Manfaat dari analisis rasio keuangan menurut Fahmi (2012:109) adalah sebagai berikut :

1) Analisis rasio keuangan sangat bermanfaat untuk dijadikan sebagai alat menilai kinerja dan prestasi perusahaan.

2) Analisis rasio keuangan sangat bermanfaat bagi pihak manajemen sebagai rajukan untuk perencanaan.

3) Analisis rasio keuangan dapat dijadikan sebagai alat untuk mengevaluasi kondisi suatu perusahaan dari perspektif keuangan.

4) Analisis rasio keuangan juga bermanfaat bagi para kreditor dapat digunakan untuk memperkirakan potensi resiko yang dihadapi dikaitkan dengan adanya jaminan kelangsungan pembayaran bunga dan pengembalian pokok pinjaman.

5) Analisis rasio keuangan dapat djadikan sebagai penilaian bagi pihak stakeholder organisasi.

\section{b. Rasio Likuiditas}

Menurut Subramanyam (2010:10), likuiditas adalah kemampuan perusahaan untuk menghasilkan kas dalam jangka pendek untuk memenuhi kewajibannya dan bergantung pada arus kas perusahaan 
serta komponen aset serta kewajiban lancarnya. Pendapat lain dari Kasmir (2014:129) menyatakan bahwa rasio likuiditas (likuidity ratio) merupakan rasio yang menggambarkan kemampuan perusahaan dalam memenuhi kewajiban (utang) jangka pendek.

Berdasarkan berbagai pendapat para ahli maka dapat disimpulkan bahwa likuiditas merupakan kemampuan suatu perusahaan dalam memenuhi kewajiban jangka pendeknya pada saat ditagih dengan menggunakan aktiva lancar perusahaan. Rasio yang digunakan untuk menghitung tingkat likuiditas suatu perusahaan adalah :

\section{1) Quick Ratio}

Quick ratio atau acid test ratio merupakan rasio yang menunjukkan kemampuan perusahaan dalam memenuhi atau membayar kewajiban atau utang lancar (utang jangka pendek) dengan aktiva lancar tanpa memperhitungkan nilai sediaan (inventory). Artinya mengabaikan nilai sediaan dengan cara dikurangi dari total aktiva lancar. Hal ini dilakukan karena sediaan dianggap memerlukan waktu relatif lebih lama untuk diuangkan, apabila perusahaan membutuhkan dana cepat untuk membayar kewajibannya dibandingkan dengan aktiva lancar lainnya (Kasmir, 2012:136).

\section{2) Current Ratio}

Rasio lancar atau current ratio merupakan rasio untuk mengukur kemampuan perusahaan dalam membayar kewajiban jangka pendek atau utang yang segera jatuh tempo pada saat ditagih secara keseluruhan. Dengan kata lain, seberapa banyak aktiva lancar yang tersedia untuk menutupi kewajiban jangka pendek atau utang yang segera jatuh tempo (Kasmir, 2012:134).

\section{3) Cash Ratio}

Rasio kas atau cash ratio merupakan alat yang digunakan untuk mengukur seberapa besar uang kas yang tersedia untuk membayar utang. Ketersediaan uang kas yang dapat ditunjukkan dari tersedianya dana kas atau setara dengan kas seperti rekening giro atau tabungan di bank (yang dapat ditarik setiap saat). Dapat dikatakan rasio ini menunjukkan kemampuan sesungguhnya bagi perusahaan untuk membayar utang-utang jangka pendeknya, (Kasmir, 2012:138).

\section{c. Rasio Profitabilitas}

Menurut Kasmir (2014:114), rasio profitabilitas merupakan rasio yang menilai kemampuan perusahaan dalam mencari keuntungan atau laba dalam suatu periode tertentu. Sedangkan menurut Periansya (2015:42), menyatakan bahwa rasio profitabilitas atau rasio keuntungan mengukur seberapa besar kemampuan perusahaan memperoleh laba dalam hubungan dengan penjualan, asset mapun laba dan modal sendiri.

Berdasarkan berbagai pendapat maka dapat disimpulkan bahwa rasio profitabilitas merupakan rasio yang digunakan untuk mengukur kemampuan dan keberhasilan perusahaan dalam memperoleh laba atau keuntungan.

Rasio yang digunakan untuk menghitung tingkat profitabilitas suatu perusahaan adalah :

\section{1) Net Profit Margin}

Menurut Rudianto (2013:192) Net Profit Margin adalah ukuran persentase dari setiap hasil penjualan sesudah dikurangi semua biaya dan pengeluaran, termasuk bunga dan pajak. Rasio ini berguna untuk mengukur tingkat efektivitas perusahaan dalam menghasilkan keuntungan dengan melihat 
besarnya laba bersih setelah pajak dalam hubungannya dengan penjualan.

\section{2) Return On Investment}

Rasio ini menggambarkan
kemampuan menghasilkan keuntungan dari setiap satu rupiah asset yang digunakan. Dengan mengetahui rasio ini dapat dinilai apakah perusahaan efisien dalam memanfaatkan assetnya dalam kegiatan operasi perusahaan, (Rudianto, 2013:192).

\section{3) Return On Equity}

Rasio ini menunjukkan kemampuan manajemen dalam memaksimalkan ekuitas yang digunakan oleh perusahaan, (Rudianto, 2013:192).

\section{Metode Penelitian}

Metode penelitian yang dipergunakan adalah metode Deskriptif. Menurut Sugiyono (2013:147), metode deskriptif adalah metode yang digunakan untuk menganalisis data dengan cara mendeskriptifkan atau menggambarkan data yang telah terkumpul sebagaimana adanya tanpa bermaksud membuat kesimpulan yang berlaku untuk umum atau generalisasi.

\section{a. Penelitian Terdahulu}

Rayun Wilanda, (2017) meneliti tentang Analisis Rasio Aktivitas dan Rasio Profitabilitas terhadap Kinerja Keuangan pada CV Tehnik Putra Perkasa di Baturaja. Berdasarkan hasil analisis bahwa hasil rasio aktivitas pada CV Tehnik Putra Perkasa di Baturaja dari tahun 2013-2016 masih ada yang dibawah standar industri. Receivable turnover kurang baik karena masih jauh dari 15 kali. Total assets turnover sudah baik karena sudah diatas 2 kali. Fixed assets turnover sudah baik karena sudah jauh diatas 5 kali. Maka kinerja keuangan perusahaan berdasarkan rasio aktivitas dinyatakan kurang baik karena perusahaan belum mampu menekan modal kerja perusahaan yang ditanamkan pada piutang serta perusahaan belum mampu memaksimalkan kapasitas aktiva.

Hasil rasio profitabilitas pada CV Tehnik Putra Perkasa di Baturaja tahun 2013-2016 keseluruhannya kurang baik. Gross profit margin kurang baik karena dibawah $30 \%$. Net profit margin dinyatakan kurang baik karena masih dibawah 20\%. Return on investment kurang baik karena masih dibawah $30 \%$. Maka kinerja keuangan perusahaan berdasarkan rasio aktivitas dinyatakan kurang baik karena meningkatnya biaya tidak langsung yang relative tinggi terhadap perusahaan, perubahan harga jual dan harga harga pokok penjualan. Perusahaan juga belum mampu mengelola kegiatan operasionalnya dengan efektif dan efisien dalam merencanakan dan melaksanakan strategi seperti dalam penggunaan dana yang tidak sesuai dengan target pekerjaan.

Selanjutnya penelitian yang dilakukan oleh Masnuripa Harahap, (2018) yang berjudul Analisis Rasio Likuiditas Sebagai Alat Penelitian Untuk Mengukur Kinerja Keuangan pada PT Prodia Widyahusada Tbk. Berdasarkan hasil analisis data yang telah dilakukan dapat disimpulkan kinerja keuangan PT Prodia Widyahusada Tbk tahun 2013-2016 berdasarkan current ratio dinyatakan cukup baik karena hasil perhitungan selama 4 tahun berada dibawah standar industri $200 \%$ yaitu $128,29 \%$.

Quick ratio dinyatakan baik karena hasil perhitungan selama 4 tahun hampir mendekati angka standar industri 150\% yaitu $112,43 \%$. Cash ratio dinyatakan 
kurang karena hasil perhitungan selama 4 tahun berada dibawah angka standar industri $50 \%$ yaitu $23,84 \%$. Inventory to net working capital dinyatakan sangat baik karena hasil perhitungan selama 4 tahun diatas standar industri $12 \%$ yaitu $56,19 \%$.

\section{b. Teknik Pengumpulan Data}

Teknik pengumpulan data yang digunakan adalah observasi, wawancara dan studi pustaka. Dalam penelitian ini jenis data yang digunakan adalah data primer dan sekunder.

\section{c. Teknik Analisis Data}

Teknik analisis data yang digunakan dalam penelitian ini adalah analisis data kualitatif dan analisis data kuantitatif. Teknik analisis data kuantitatif melakukan perhitungan dengan menggunkan rumusrumus rasio likuiditas dan rasio profitabilitas.

\section{1) Rasio Likuiditas}

a) Quick Ratio

Quick Ratio $=\frac{\text { Akuva Lancar-rersealaan }}{\text { Hutang Lancar }} \times 100 \%$

b) Current Ratio

Current Ratio $=\frac{\text { Aktiva Lancar }}{\text { Hutang Lancar }} \times 100 \%$

c) Cash Ratio

Cash Ratio $=\frac{\text { kastsurat berharga }}{\text { Hutang Lancar }} \times 100 \%$

2) Rasio Profitabilitas

a) Net Profit Margin

Net Profit Margin $=\frac{\text { Laba Bersih setelah pajak }}{\text { Penjualan Bersih }} \times 100 \%$ b) Return On Investment

Retum On Irvestment $=\frac{\text { Laba Bersih setelah pajak }}{\text { Total Aktiva }} \times 100 \%$

c) Return On Equity

Retum On Equity $=\frac{\text { Laba Bersih setelah pajak }}{\text { Ekuitas }} \times 100 \%$

\section{Pembahasan}

Laporan keuangan adalah informasi yang dibuat oleh pihak perusahaan berdasarkan hasil dari kegiatan atau aktivitas perusahaan yang disajikan pada akhir periode akuntansi dimana informasi tersebut dapat digunakan bagi pihak-pihak yang berkepentingan dalam mengambil keputusan ekonomi. Data-data yang digunakan dalam menganalisis rasio likuiditas dan rasio profitabilitas bertujuan untuk mengetahui keadaan keuangan perusahaan dalam penelitian ini diperoleh dari laporan keuangan Perusahaan Daerah Air Minum Kabupaten Ogan Komering Ulu tahun 2014-2017.

Laporan keuangan Perusahaan Daerah Air Minum Kabupaten OKU tahun 2014 2017 adalah sebagai berikut :

\begin{tabular}{|c|c|c|c|c|}
\hline \multicolumn{5}{|c|}{ Tabel3. } \\
\hline \multicolumn{5}{|c|}{ PDAM Kabupaten Ogan Komering Ulu } \\
\hline \multicolumn{5}{|c|}{ LAPORAN LABA RIGI KOMPREHENSIF } \\
\hline \multicolumn{5}{|c|}{ Untuk Tahum Yang Berakhir pada Tanggal 31 Desember 2014-2017 } \\
\hline & 2014 & 2015 & 2016 & 2017 \\
\hline PENDAPATANUSAHA & Rp 18,979,700,541.00 & Rp20,086,946,1355.00 & Rp 19,957,493,111.00 & Rp 21,834,736,007,00 \\
\hline \multicolumn{5}{|l|}{ BEBAN LSAHA } \\
\hline Beban Pegawai & Rp $8,825,411,772,00$ & Rp 9,502,479,390.00 & Rp $9,971,631,858.00$ & Rp 10,553,008,893:00 \\
\hline Beban Bahan Bakar & $\operatorname{Rp} \quad 524,596,888.00$ & $\operatorname{Rp} \quad 523,215,221,00$ & Rp $\quad 179,272,241.00$ & Rp $\quad 161,816,500.00$ \\
\hline Beban Listik & Rp $\quad 3,966,500,633.00$ & Rp 4,675,842,691.00 & Rp $4,003,777,627,00$ & Rp $5,093,280,300,00$ \\
\hline Beban Penyusutan & Rp $4,135,451,191.85$ & Rp 3,395,752,774.20 & Rp $3,867,295,997,53$ & Rp $3,630,853,350.35$ \\
\hline Beban Penyishan Ushaha & Rp $\quad 706,110,159,00$ & $\operatorname{Rp} \quad 378,140,796,00$ & $\operatorname{Rp} \quad 473,050,473,00$ & Rp $\quad 571,297,890.00$ \\
\hline Beban Pemeltharaan & $\operatorname{Rp} \quad 1,557,518,896,00$ & Rp $1,859,731,645.00$ & $\operatorname{Rp} \quad 1,926,043,702,00$ & Rp $1,148,064,160.00$ \\
\hline Beban Operasi Lainya & Rp $1,759,469,965.97$ & Rp 2,251,509,004.34 & Rp $\quad 2,201,001,598.74$ & Rp $\quad 1,107,751,286.99$ \\
\hline Jumlah Beban Lsaha & Rp 21,475,059,055,82 & \begin{tabular}{|l|}
$\mathrm{Rp} 23,086,61,521,54$ \\
\end{tabular} & $\operatorname{Rp} 23,222,073,497,27$ & Rp 22,566,072,3800,34 \\
\hline LABA (RIGI) BERSHH & $\operatorname{Rp}(2,495,358,964.82)$ & $\operatorname{Rpp}(2,999,725,386,544$ & $\operatorname{Rp}(3,264,580,386,27)$ & Rp $\quad(731,335,773,34$ \\
\hline & & & & \\
\hline
\end{tabular}




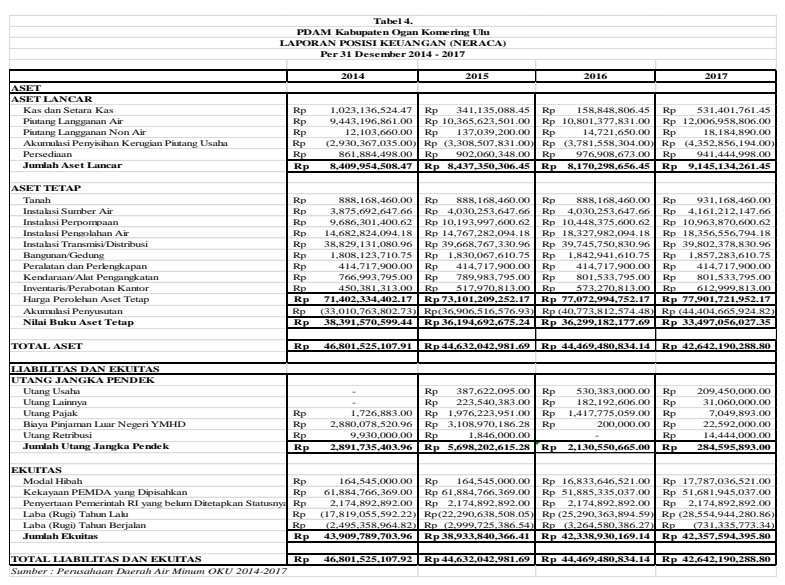

Untuk mengetahui keadaan keuangan Perusahaan Daerah Air Minum Kabupaten Ogan Komering Ulu ditinjau dari segi analisis Rasio Likuiditas dan Rasio Profitabilitas. Adapun rasio yang digunakan untuk menganalisis keadaan keuangan Perusahaan Daerah Air Minum Kabupaten Ogan Komering Ulu, sebagai berikut :

\section{a. Analisis Rasio Likuiditas}

Menurut Kasmir (2014:129) Rasio Likuiditas merupakan rasio yang menggambarkan kemampuan perusahaan dalam memenuhi kewajiban (utang) jangka pendek. Pengukuran rasio likuiditas terdiri dari :

\section{1) Quick Ratio}

Quick ratio atau acid test ratio merupakan rasio yang menunjukkan kemampuan perusahaan dalam memenuhi atau membayar kewajiban atau utang lancar (utang jangka pendek) dengan aktiva lancar tanpa memperhitungkan nilai sediaan (inventory).

Berikut ini perhitungan Quick ratio Perusahaan Daerah Air Minum Kabupaten OKU periode 2014-2017 :

Tahun 2014

Quick Ratio $=\frac{\operatorname{Rp~} 8.409 .954 .508,47-\operatorname{Rp~} 861.884 .498,00}{\operatorname{Rp} 2.891 .735 .403,96} \times 100 \%=261 \%$

Berdasarkan hasil perhitungan dapat dilihat bahwa quick ratio pada tahun 2014 adalah $261 \%$ yang berarti setiap Rp 1,hutang lancar dijamin dengan aktiva lancar dikurangi persediaan sebesar Rp 2,61,--

\section{Tahun 2015}

Quick Ratio $=\frac{\operatorname{Rp} 8.437 .350 .306,45-\operatorname{Rp} 902.060 .348,00}{\operatorname{Rp} 5.698 .202 .615,28} \times 100 \%=132 \%$

Berdasarkan hasil perhitungan dapat dilihat bahwa quick ratio pada tahun 2015 quick ratio sebesar $132 \%$ yang berarti setiap Rp 1,- hutang lancar dijamin dengan aktiva lancar dikurangi persediaan sebesar Rp 1,32,-. Pada tahun 2015 quick ratio mengalami penurunan dikarenakan meskipun aktiva lancar mengalami kenaikan menjadi Rp 8.437.350.306,45 dan persediaan juga mengalami kenaikan menjadi Rp 902.060.348,00, tetapi hal ini juga diikuti oleh hutang lancar yang juga mengalami kenaikan menjadi Rp 5.698.202.615,28.

\section{Tahun 2016}

Quick Ratio $=\frac{\operatorname{Rp~} 8.170 .298 .656,45-\mathrm{Rp} 976.908 .673,00}{\operatorname{Rp} 2.130 .550 .665,00} \times 100 \%=338 \%$

Berdasarkan hasil perhitungan dapat dilihat bahwa quick ratio pada tahun 2016 quick ratio sebesar $338 \%$ yang berarti setiap Rp 1,- hutang lancar dijamin dengan aktiva lancar dikurangi persediaan sebesar Rp 3,38,-. Pada tahun 2016 quick ratio mengalami peningkatan karena walaupun jumlah aktiva lancar menurun menjadi Rp 8.170.298.656,45 tetapi persediaan mengalami peningkatan menjadi Rp 976.908.673,0 sedangkan hutang lancar mengalami penurunan menjadi Rp 2.130.550.665,00.

\section{Tahun 2017}

Quick Ratio $=\frac{\operatorname{Rp} 9.145 .134 .261,45-\operatorname{Rp} 941.444 .998,00}{\operatorname{Rp} 284.595 .893,00} \times 100 \%=2.883 \%$ 
Berdasarkan hasil perhitungan dapat dilihat bahwa quick ratio pada tahun 2017 sebesar $2.883 \%$ yang berarti setiap Rp 1,hutang lancar dijamin dengan aktiva lancar dikurangi persediaan sebesar Rp 28,83,-. Pada tahun 2017 quick ratio terus mengalami peningkatan karena jumlah aktiva lancar meningkat menjadi Rp 9.145.134.261,45 dan walaupun persediaan juga menurun menjadi Rp 941.444.998,00 , tetapi diikuti juga hutang lancar yang mengalami penurunan menjadi Rp 284.595.893,00.

Quick ratio Perusahaan Daerah Air Minum Kabupaten OKU pada tahun 2014, dalam konsisi yang baik karena rasio berada diatas standar industri. Sedangkan pada tahun 2015 quick ratio tidak dalam kondisi yang baik karena berada dibawah standar industri. Lalu pada tahun 2016 dan 2017 tingkat quick ratio kembali berada dalam kondisi yang baik .karena diatas standar industri. Standar industri untuk quick ratio yaitu $150 \%$.

\section{2) Current Ratio}

Rasio lancar atau current ratio merupakan rasio untuk mengukur kemampuan perusahaan dalam membayar kewajiban jangka pendek atau utang yang segera jatuh tempo pada saat ditagih secara keseluruhan. Dengan kata lain, seberapa banyak aktiva lancar yang tersedia untuk menutupi kewajiban jangka pendek atau utang yang segera jatuh tempo (Kasmir, 2012:134).

Berikut ini perhitungan Current ratio Perusahaan Daerah Air Minum Kabupaten OKU periode 2014-2017 :

\section{Tahun 2014}

Current Ratio $=\frac{\operatorname{Rp} 8.409 .954 .508,47}{\operatorname{Rp} 2.891 .735 .403,96} \times 100 \%=291 \%$
Berdasarkan hasil perhitungan dapat dilihat bahwa current ratio pada tahun 2014 adalah $291 \%$. Hal ini berarti bahwa setiap Rp 1,- hutang lancar dijamin dengan Rp 2,91,- aktiva lancar.

\section{Tahun 2015}

$$
\text { Current Ratio }=\frac{\operatorname{Rp} 8.437 .350 .306,45}{\operatorname{Rp} 5.698 .202 .615,28} \times 100 \%=148 \%
$$

Berdasarkan hasil perhitungan dapat dilihat bahwa current ratio pada tahun 2015 current ratio sebesar $148 \%$ yang berarti setiap Rp 1,- hutang lancar dijamin dengan Rp 1,48,- aktiva lancar. Pada tahun 2015 current ratio mengalami penurunan dikarenakan jumlah aktiva mengalami kenaikan menjadi Rp 8.437.350.306,45 yang juga diikuti dengan naiknya jumlah hutang lancar menjadi Rp 5.698.202.615,28.

\section{Tahun 2016

$$
\text { Curvent Ratio }=\frac{\operatorname{Rp} 8.170 .298 .656,45}{\operatorname{Rp} 2.130 .550 .665,00} \times 100 \%=383 \%
$$

Berdasarkan hasil perhitungan dapat dilihat bahwa current ratio pada tahun 2016 current ratio sebesar 383\% yang berarti bahwa setiap Rp 1,- hutang lancar dijamin dengan $\mathrm{Rp}$ 3,83,- aktiva lancar. Tahun 2016 current ratio mengalami kenaikan karena walaupun adanya penurunan jumlah aktiva lancar menjadi Rp 8.170.298.656,45 tetapi jumlah hutang lancar juga turun menjadi Rp 2.130.550.665,00.

\section{Tahun 2017}

wrent Ratio $=\frac{\operatorname{Rp} 9.145 .134 .261,45}{\operatorname{Rp} 284.595 .893,00} \times 100 \%=3.213 \%$ 
Berdasarkan hasil perhitungan dapat dilihat bahwa current ratio pada tahun 2017 current ratio-nya sebesar $3.213 \%$ yang berarti setiap Rp 1,- hutang lancar dijamin dengan Rp 32,13,- aktiva lancar. Tahun 2017 tingkat current ratio kembali mengalami kenaikan yang dikarenakan naiknya aktiva lancar menjadi Rp 9.145.134.261,45 dan diikuti dengan turunnya jumlah hutang lancar menjadi Rp 284.595.893,00.

Current ratio Perusahaan Daerah Air Minum Kabupaten OKU tahun 2014 dalam kondisi yang baik karena berada diatas standar industri. Lalu pada tahun 2015 quick ratio berada dibawah standar industri sehingga kondisi nya tidak baik. Sedangkan pada tahun 2016 dan tahun 2017 current ratio kembali dinyatakan dalam kondisi yang baik karena berada diatas standar industri. Standar industri untuk current ratio adalah $200 \%$.

\section{3) Cash Ratio}

Rasio kas atau cash ratio merupakan alat yang digunakan untuk mengukur seberapa besar uang kas yang tersedia untuk membayar utang. Ketersediaan uang kas yang dapat ditunjukkan dari tersedianya dana kas atau setara dengan kas seperti rekening giro atau tabungan di bank (yang dapat ditarik setiap saat). Dapat dikatakan rasio ini menunjukkan kemampuan sesungguhnya bagi perusahaan untuk membayar utang-utang jangka pendeknya (Kasmir, 2012:138).

Berikut ini perhitungan Current ratio Perusahaan Daerah Air Minum Kabupaten OKU periode 2014-2017 :

\section{Tahun 2014}

$$
\text { Cash Ratio }=\frac{\operatorname{Rp} 1.023 \cdot 136.524,47}{\operatorname{Rp} 2.891 .735 .403,96} \times 100 \%=35 \%
$$

Berdasarkan hasil perhitungan dapat dilihat bahwa cash ratio pada tahun 2014 adalah 35\%, artinya setiap Rp 1,- hutang lancar dijamin oleh Rp 0,35 uang kas.

\section{Tahun 2015}

$$
\text { Cash Ratio }=\frac{\operatorname{Rp} 341.135 .088,45}{\operatorname{Rp} 5.698 .202 .615,28} \times 100 \%=6 \%
$$

Berdasarkan hasil perhitungan dapat dilihat bahwa cash ratio pada Tahun 2015 cash ratio sebesar $6 \%$ artinya setiap $\mathrm{Rp} 1,-$ hutang lancar dijamin oleh Rp 0,06 uang kas. Pada tahun 2015 cash ratio mengalami penurunan karena jumlah kas yang menurun menjadi Rp 341.135.088,45 dan jumlah hutang lancar yang mengalami kenaikan menjadi Rp 5.698.202.615,28.

\section{Tahun 2016}

$$
\text { Cash Ratio }=\frac{\operatorname{Rp} 158.848 .806,45}{\operatorname{Rp} 2.130 .550 .665,00} \times 100 \%=7 \%
$$

Berdasarkan hasil perhitungan dapat dilihat bahwa cash ratio pada tahun 2016 cash ratio sebesar $7 \%$ yang artinya setiap Rp 1,- hutang lancar akan dijamin dengan Rp 0,07 uang kas. Tahun 2016 cash ratio mengalami sedikit kenaikan dari tahun sebelumnya karena walaupun jumlah kas menurun menjadi Rp 158.848.806,45 tetapi jumlah hutang lancar juga mengalami penurunan menjadi Rp 2.130.550.665,00.

\section{Tahun 2017}

Cash Ratio $=\frac{\operatorname{Rp} 531.401 .761,45}{\operatorname{Rp} 284.595 .893,00} \times 100 \%=187 \%$

Berdasarkan hasil perhitungan dapat dilihat bahwa cash ratio pada tahun 2017 cash ratio sebesar $187 \%$ artinya setiap $\mathrm{Rp}$ 1,- hutang lancar akan dijamin oleh Rp 1,87 uang kas. Tahun 2017 cash ratio kembali mengalami kenaikan karena 
jumlah kas yang mengalami kenaikan menjadi Rp 531.401.761,45 dan jumlah hutang lancar yang mengalami penurunan menjadi Rp 284.595.893,00.

Cash ratio Perusahaan Daerah Air Minum Kabupaten OKU pada tahun 2014, 2015 dan 2016 tidak dalam kondisi yang baik yaitu $35 \%$, 6\%, dan $7 \%$ karena berada dibawah standar industri. Lalu pada tahun 2017 tingkat cash ratio mengalami kenaikan menjadi $187 \%$ dan dinyatakan dalam kondisi yang baik karena berada diatas standar industri. Standar industri untuk cash ratio adalah $50 \%$.

\section{Analisis Rasio Profitabilitas}

Menurut Kasmir (2012:196) Rasio profitabilitas adalah rasio untuk menilai kemampuan perusahaan dalam mencari keuntungan. Pengukuran rasio profitabilitas terdiri dari :

\section{1) Net Profit Margin}

Menurut Rudianto (2013:192) Net Profit Margin adalah ukuran persentase dari setiap hasil penjualan sesudah dikurangi semua biaya dan pengeluaran, termasuk bunga dan pajak. Rasio ini berguna untuk mengukur tingkat efektivitas perusahaan dalam menghasilkan keuntungan dengan melihat besarnya laba bersih setelah pajak dalam hubungannya dengan penjualan.

Berikut ini perhitungan Net Profit Margin Perusahaan Daerah Air Minum Kabupaten OKU periode 2014-2017 :

\section{Tahun 2014}

$$
\text { Wet Profit 1Gargin }=\frac{(\operatorname{Rp} 2.455 .358 .964,83)}{\operatorname{Rp} 18.979 .700541,00} \times 100 \%=(13,15 \% \%)
$$

Berdasarkan hasil perhitungan dapat dilihat bahwa net profit margin pada tahun 2014 sebesar $(13,15 \%)$ yang artinya setiap
Rp 1,- penjualan perusahaan mengalami kerugian sebesar Rp 0,1315.

\section{Tahun 2015}

$$
\text { NetProfu Margin }=\frac{(\text { Rp 2999.725.386,54) }}{\text { Rp 20.086.946.135;,00 }} \times 100 \%=(14,93 \%)
$$

Berdasarkan hasil perhitungan dapat dilihat bahwa net profit margin pada tahun 2015 net profit margin sebesar (14,93\%) yang artinya setiap $\mathrm{Rp} 1,-$ penjualan perusahaan mengalami kerugian sebesar Rp 0,1493. Pada tahun 2015 net profit margin mengalami penurunan karena jumlah rugi mengalami kenaikan dari tahun sebelumnya menjadi Rp 2.999.725.386,5, dan jumlah penjualan yang meningkat menjadi Rp 20.086.946.135,00.

\section{Tahun 2016}

$$
\text { Net Profit Margin }=\frac{(\operatorname{Rp} 3.264 .580 .386,27)}{\operatorname{Rp} 19957.493 .111,00} \times 100 \%=(16,36 \%)
$$

Berdasarkan hasil perhitungan dapat dilihat bahwa net profit margin pada tahun 2016 tingkat net profit margin sebesar $(16,36 \%)$ yang artinya setiap $\mathrm{Rp} 1$,penjualan perusahaan mengalami kerugian sebesar Rp 0,1636. Tahun 2016 tingkat net profit margin kembali mengalami penurunan yang juga dikarenakan naiknya jumlah rugi dari tahun sebelumnya menjadi Rp 3.264.580.386,27 dan jumlah penjualan yang menurun menjadi Rp 19.957.493.111,00.

\section{Tahun 2017}

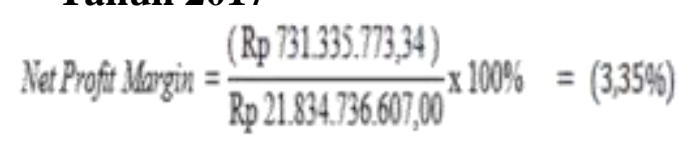

Berdasarkan hasil perhitungan dapat dilihat bahwa net profit margin pada tahun 2017 net profit margin sebesar (3,35\%) 
yang artinya setiap $\mathrm{Rp} 1,-$ penjualan perusahaan mengalami kerugian sebesar Rp 0,035. Tahun 2017 net profit margin mengalami peningkatan walaupun masih bernilai negatif tetapi hal ini masih lebih baik dari tahun sebelumnya karena jumlah rugi jauh mengalami penurunan menjadi Rp 731.335.773,34 dan jumlah penjualan yang meningkat menjadi Rp 21.834.736.607,00.

Net profit margin Perusahaan Daerah Air Minum Kabupaten OKU pada tahun 2014 sebesar $-13,15 \%$, tahun 2015 sebesar $-14,93 \%$, tahun 2016 sebesar $-16,36 \%$, lalu pada tahun 2017 sebesar $-3,35 \%$. Hal ini menunjukkan bahwa net profit margin PDAM Kabupaten OKU meskipun semua nilai negatif akan tetapi pada tahun 2017 berjalan sedikit lebih baik dari tahun-tahun sebelumnya. Akhirnya net profit margin PDAM Kabupaten OKU dari tahun 2014 sampai tahun 2017 dinyatakan berada kondisi yang tidak baik.

\section{2) Return On Investment}

Rasio ini menggambarkan kemampuan perusahaan untuk menghasilkan keuntungan dari setiap satu rupiah asset yang digunakan. Dengan mengetahui rasio ini dapat dinilai apakah perusahaan efisien dalam memanfaatkan assetnya dalam kegiatan operasi perusahaan. (Rudianto, 2013:192).

Berikut ini perhitungan Return On Investment Perusahaan Daerah Air Minum Kabupaten OKU periode 2014-2017 :

\section{Tahun 2014}

Reton On Lnestment $=\frac{(\operatorname{Rp} 2495.358 .964,83)}{\operatorname{Rp} 46.801 .525 .107,91} \times 100 \%=(5,3396)$

Berdasarkan hasil perhitungan diatas dapat dilihat bahwa return on investment pada tahun 2014 sebesar $(5,33 \%)$ yang artinya setiap $\mathrm{Rp} 1,-$ modal yang diinvestasikan dalam keseluruhan aktiva, perusahaan mengalami kerugian sebesar Rp 0,0533.

\section{Tahun 2015}

$$
\text { Retum On invertanent }=\frac{(\operatorname{Rp} 2.999 .725 .386,54)}{\operatorname{Rp} 44.692 .042981,69} \times 100 \%=(6,7296)
$$

Berdasarkan hasil perhitungan diatas dapat dilihat bahwa return on investment pada tahun 2015 return on investment sebesar $(6,72 \%)$ yang artinya setiap Rp 1,modal yang diinvestasikan dalam keseluruhan aktiva, perusahaan mengalami kerugian sebesar Rp 0,0672. Pada tahun 2015 ROI mengalami penurunan karena jumlah rugi mengalami kenaikan dari tahun sebelumnya menjadi Rp 2.999.725.386,54, dan jumlah aktiva yang menurun menjadi Rp 44.632.042.981,69.

\section{Tahun 2016}

$$
\text { Return On Inverdment }=\frac{(\text { Rp 3264.580386.27) }}{\operatorname{Rp} 44.469 .480 .834,14} \times 10096=(7,34 \%)
$$

dapat dilihat bahwa return on investment pada tahun 2016 tingkat return on investment sebesar $(7,34 \%)$ yang artinya setiap Rp 1,- modal yang yang diinvestasikan dalam keseluruhan aktiva, perusahaan mengalami kerugian sebesar Rp 0,0734. Tahun 2016 tingkat ROI kembali mengalami penurunan yang juga dikarenakan naiknya jumlah rugi dari tahun sebelumnya menjadi Rp 3.264.580.386,27 dan jumlah aktiva yang menurun menjadi Rp 44.469.480.834,14.

\section{Tahun 2017}

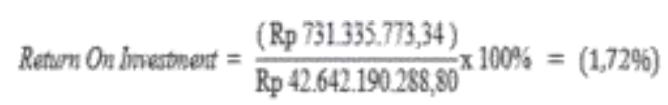

Berdasarkan hasil perhitungan diatas dapat dilihat bahwa return on 
investment pada tahun 2017 return on investment sebesar $(1,72 \%)$ yang artinya setiap Rp 1,- modal yang diinvestasikan dalam keseluruhan aktiva, perusahaan mengalami kerugian sebesar Rp 0,0172. Tahun 2017 ROI mengalami peningkatan walaupun masih bernilai negatif tetapi hal ini masih lebih baik dari tahun sebelumnya karena jumlah rugi jauh mengalami penurunan menjadi Rp 731.335.773,34 dan jumlah aktiva yang menurun menjadi Rp 42.642.190.288,80.

Return on investment Perusahaan Daerah Air Minum Kabupaten OKU pada tahun 2014 sebesar $-5,33 \%$, tahun 2015 sebesar $-6,72 \%$, tahun 2016 sebesar $7,34 \%$, lalu pada tahun 2017 sebesar $1,72 \%$. Hal ini menunjukkan bahwa return on investment PDAM Kabupaten OKU meskipun semua nilai negatif akan tetapi pada tahun 2017 berjalan sedikit lebih baik dari tahun-tahun sebelumnya. Akhirnya Return on investment PDAM Kabupaten OKU dari tahun 2014 sampai tahun 2017 dinyatakan berada kondisi yang tidak baik.

\section{3) Return On Equity}

Rasio ini menunjukkan kemampuan manajemen dalam memaksimalkan ekuitas yang digunakan oleh perusahaan. (Rudianto, 2013:192).

Berikut ini perhitungan Return On Investment Perusahaan Daerah Air Minum Kabupaten OKU periode 2014-2017 :

Tahun 2014

$$
\text { Retion On Equity }=\frac{(\operatorname{Rp} 2495.358,964,83)}{\operatorname{Rp} 43.909 .789 .703,95} \times 100 \%=(5,6896)
$$

Berdasarkan hasil perhitungan diatas dapat dilihat bahwa return on equity pada tahun 2014 sebesar $(5,68 \%)$ yang artinya setiap Rp 1,- jumlah ekuitas yang tersedia, perusahaan mengalami kerugian sebesar Rp 0,0568.

\section{Tahun 2015}

Retum On Equity $=\frac{(\operatorname{Rp} 2999.725 .386,54)}{\operatorname{Rp} 38.933 .840 .366,41} \times 100 \%$ s $=(7,7096)$

Berdasarkan hasil perhitungan diatas dapat dilihat bahwa return on equity pada tahun 2015 return on equity sebesar (7,70\%) yang artinya setiap Rp 1,- jumlah ekuitas yang tersedia, perusahaan mengalami kerugian sebesar $\mathrm{Rp}$ 0,077. Pada tahun 2015 ROE mengalami penurunan karena jumlah rugi mengalami kenaikan dari tahun sebelumnya menjadi Rp 2.999.725.386,54, dan jumlah ekuitas yang menurun menjadi Rp 38.933.840.366,41.

\section{Tahun 2016}

$$
\text { Retwen On Equity }=\frac{(\mathrm{Rp} 3.264 .580 .386,27)}{\mathrm{Rp} 42.338 .930 .169,14} \times 100 \%=(7,71 \%)
$$

Berdasarkan hasil perhitungan diatas dapat dilihat bahwa return on equity pada tahun 2016 tingkat return on equity sebesar $(7,71 \%)$ yang artinya setiap Rp 1,jumlah ekuitas yang tersedia, perusahaan mengalami kerugian sebesar Rp 0,0771. Tahun 2016 tingkat ROE kembali mengalami penurunan yang juga dikarenakan naiknya jumlah rugi dari tahun sebelumnya menjadi Rp 3.264.580.386,27 dan jumlah ekuitas yang meningkat menjadi Rp 42.338.930.169,14.

\section{Tahun 2017}

$$
\text { Rethon On Equity }=\frac{(\operatorname{Rp} 731.335 .773,34)}{\operatorname{Rp} 42.357 .594 .396,80} \times 100 \%=(1,73 \%)
$$

Berdasarkan hasil perhitungan diatas dapat dilihat bahwa return on equity pada tahun 2017 return on equity sebesar $(1,73 \%)$ yang artinya setiap Rp 1,- jumlah ekuitas yang tersedia, perusahaan mengalami kerugian sebesar Rp 0,0173. Tahun 2017 ROE mengalami peningkatan 
walaupun masih bernilai negatif tetapi hal ini masih lebih baik dari tahun sebelumnya karena jumlah rugi jauh mengalami penurunan menjadi $\mathrm{Rp}$ 731.335.773,34 dan jumlah ekuitas yang meningkat menjadi Rp 42.357.594.396,80.

Return on equity Perusahaan Daerah Air Minum Kabupaten OKU pada tahun 2014 sebesar $-5,68 \%$, tahun 2015 sebesar $7,70 \%$, tahun 2016 sebesar $-7,71 \%$, lalu pada tahun 2017 sebesar $-1,73 \%$. Hal ini menunjukkan bahwa return on equity PDAM Kabupaten OKU meskipun semua nilai negatif akan tetapi pada tahun 2017 berjalan sedikit lebih baik dari tahun-tahun sebelumnya. Akhirnya Return on equity PDAM Kabupaten OKU dari tahun 2014 sampai tahun 2017 dinyatakan berada kondisi yang tidak baik.

Dari perhitungan rasio likuiditas yang dilakukan pada Perusahaan Daerah Air Minum Kabupaten OKU menunjukkan hasil yang dapat dilihat pada tabel 5 sebagai berikut :

Tabel 5

Analisis Rasio Likuiditas

Perusahaan Daerah Air Minum Kabupaten OKU Tahun 2014 - 2017

\begin{tabular}{|l|c|c|c|c|}
\hline \multirow{2}{*}{$\begin{array}{c}\text { Rasio } \\
\text { Likuiditas }\end{array}$} & \multicolumn{4}{|c|}{ Tahun } \\
\cline { 2 - 5 } & $\mathbf{2 0 1 4}$ & $\mathbf{2 0 1 5}$ & $\mathbf{2 0 1 6}$ & $\mathbf{2 0 1 7}$ \\
\hline Quick Ratio & $261 \%$ & $132 \%$ & $338 \%$ & $2.883 \%$ \\
\hline Current Ratio & $291 \%$ & $148 \%$ & $383 \%$ & $3.213 \%$ \\
\hline Cash Ratio & $35 \%$ & $6 \%$ & $7 \%$ & $187 \%$ \\
\hline
\end{tabular}

Keadaan keuangan berdasarkan hasil perhitungan rasio likuiditas pada Perusahaan Daerah Air Minum Kabupaten OKU yang diukur dari quick ratio menggambarkan keadaan keuangan dalam kondisi yang baik pada tahun 2014, tahun 2016, dan tahun 2017 karena berada diatas standar industri untuk quick ratio yaitu
150\%. Sedangkan pada tahun 2015 menggambarkan keadaan keuangan PDAM Kabupaten OKU dalam konsisi tidak baik. Berdasarkan perhitungan current ratio Perusahaan Daerah Air Minum Kabupaten OKU memiliki keadaan keuangan dalam kondisi yang baik pada tahun 2014, tahun 2016, dan tahun 2017 karena berada diatas standar industri untuk current ratio yaitu $200 \%$. Sedangkan untuk tahun 2015 keadaan keuangan dalam kondisi yang tidak baik. Lalu berdasarkan perhitungan cash ratio Perusahaan Daerah Air Minum Kabupaten OKU memiliki keadaan keuangan dalam kondisi yang baik hanya pada tahun 2017 karena berada diatas standar industri untuk cash ratio yaitu 50\%. Sedangkan pada tahun 2014, tahun 2015, dan tahun 2016 keadaan keuangan dalam kondisi yang tidak baik.

Dari perhitungan rasio profitabilitas yang dilakukan pada Perusahaan Daerah Air Minum Kabupaten OKU menunjukkan hasil yang dapat dilihat pada tabel 6 sebagai berikut :

Tabel 6

Analisis Rasio Profitabilitas

Perusahaan Daerah Air Minum Kabupaten OKU Tahun 2014 - 2017

\begin{tabular}{|l|c|c|c|c|}
\hline \multirow{2}{*}{$\begin{array}{l}\text { Rasio } \\
\text { Profitabilitas }\end{array}$} & \multicolumn{4}{|c|}{ Tahun } \\
\cline { 2 - 5 } & $\mathbf{2 0 1 4}$ & $\mathbf{2 0 1 5}$ & $\mathbf{2 0 1 6}$ & $\mathbf{2 0 1 7}$ \\
\hline $\begin{array}{l}\text { Net Profit } \\
\text { Margin }\end{array}$ & $(13,15 \%)$ & $(14,93 \%)$ & $(16,36 \%)$ & $(3,35 \%)$ \\
\hline $\begin{array}{l}\text { Return On } \\
\text { Investment }\end{array}$ & $(5,33 \%)$ & $(6,72 \%)$ & $(7,34 \%)$ & $(1,72 \%)$ \\
\hline $\begin{array}{l}\text { Return On } \\
\text { Equity }\end{array}$ & $(5,68 \%)$ & $(7,70 \%)$ & $(7,71 \%)$ & $(1,73 \%)$ \\
\hline
\end{tabular}

Keadaan keuangan berdasarkan hasil perhitungan rasio profitabilitas pada Perusahaan Daerah Air Minum Kabupaten OKU yang diukur dari net profit margin menggambarkan keadaan keuangan dalam kondisi yang tidak baik pada tahun 2014, 
tahun 2015, tahun 2016, dan tahun 2017 karena semua nilai rasio net profit margin menunjukkan nilai negatif. Walaupun demikian net profit margin tahun 2017 sedikit lebih baik jika dibandingkan dengan tahun-tahun sebelumnya. Berdasarkan perhitungan return on investment Perusahaan Daerah Air Minum Kabupaten OKU juga memiliki keadaan keuangan dalam kondisi yang tidak baik pada tahun 2014, tahun 2015, tahun 2016, dan tahun 2017 karena semua nilai rasio return on investment menunjukkan nilai negatif. Namun jika dibandingkan dengan tahun-tahun sebelumnya return on investment pada tahun 2017 sedikit berjalan lebih baik. Lalu berdasarkan perhitungan return on equity Perusahaan Daerah Air Minum Kabupaten OKU juga memiliki keadaan keuangan dalam kondisi yang tidak baik pada tahun 2014, tahun 2015, tahun 2016, dan tahun 2017 karena semua nilai rasio return on equity menunjukkan nilai negatif. Namun jika dibandingkan dengan tahun-tahun sebelumnya return on equity pada tahun 2017 sedikit berjalan lebih baik.

Sejalan dengan hasil penelitian terdahulu yang disusun oleh Rayun Wilanda, (2017) yang berjudul "Analisis Rasio Aktivitas dan Rasio Profitabilitas terhadap Kinerja Keuangan pada CV Tehnik Putra Perkasa di Baturaja". Berdasarkan hasil analisis data yang telah dilakukan terdapat beberapa kesimpulan, diantaranya hasil rasio aktivitas pada CV Tehnik Putra Perkasa di Baturaja dari tahun 2013-2016 masih ada yang dibawah standar industri. Receivable turnover kurang baik karena masih jauh dari 15 kali. Total assets turnover sudah baik karena sudah diatas 2 kali. Fixed assets turnover sudah baik karena sudah jauh diatas 5 kali. Maka kinerja keuangan perusahaan berdasarkan rasio aktivitas dinyatakan kurang baik karena perusahaan belum mampu menekan modal kerja perusahaan yang ditanamkan pada piutang serta perusahaan belum mampu memaksimalkan kapasitas aktiva. Hasil rasio profitabilitas pada CV Tehnik Putra Perkasa di Baturaja tahun 2013-2016 keseluruhannya kurang baik. Gross profit margin kurang baik karena dibawah $30 \%$. Net profit margin dinyatakan kurang baik karena masih dibawah $20 \%$. Return on investment kurang baik karena masih dibawah 30\%. Maka kinerja keuangan perusahaan berdasarkan rasio aktivitas dinyatakan kurang baik karena meningkatnya biaya tidak langsung yang relative tinggi terhadap perusahaan, perubahan harga jual dan harga harga pokok penjualan. Perusahaan juga belum mampu mengelola kegiatan operasionalnya dengan efektif dan efisien dalam merencanakan dan melaksanakan strategi seperti dalam penggunaan dana yang tidak sesuai dengan target pekerjaan.

Selanjutnya penelitian yang dilakukan oleh Masnuripa Harahap, (2018) yang berjudul "Analisis Rasio Likuiditas Sebagai Alat Penelitian Untuk Mengukur Kinerja Keuangan pada PT Prodia Widyahusada Tbk". Berdasarkan hasil analisis data yang telah dilakukan dapat disimpulkan kinerja keuangan PT Prodia Widyahusada Tbk tahun 2013-2016 berdasarkan current ratio dinyatakan cukup baik karena hasil perhitungan selama 4 tahun berada dibawah standar industri 200\% yaitu 128,29\%. Quick ratio dinyatakan baik karena hasil perhitungan selama 4 tahun hampir mendekati angka standar industri $150 \%$ yaitu $112,43 \%$. Cash ratio dinyatakan kurang karena hasil perhitungan selama 4 tahun berada dibawah angka standar industri 50\% yaitu 
$23,84 \%$. Inventory to net working capital dinyatakan sangat baik karena hasil perhitungan selama 4 tahun diatas standar industri $12 \%$ yaitu $56,19 \%$.

\section{Kesimpulan}

Berdasarkan hasil perhitungan dari analisis yang telah dilakukan terhadap laporan keuangan yang telah diperoleh dari PDAM Kabupaten Ogan Komering Ulu dari tahun 2014, 2015, 2016, dan 2017 dapat diambil kesimpulan Berdasarkan rasio likuiditas melalui perhitungan quick ratio, current ratio kondisi keuangan PDAM Kabupaten Ogan Komering Ulu dari tahun 2014 - 2017 hanya pada tahun 2015 yang berada dibawah standar industri. Dan perhitungan cash ratio tahun 2014 - 2016 berada dibawah standar industri. Namun jika nilai rata-rata rasio quick ratio adalah $903,5 \%$, current ratio $1.008,75 \%$, dan cash ratio $58,75 \%$ maka kondisi perusahaan tahun 2014 - 2017 dalam kondisi yang baik karena sudah melebihi standar industri. Berdasarkan hal ini dapat disimpulkan bahwa perusahaan mampu untuk memenuhi kewajiban jangka pendeknya.

Dari tahun 2014 - 2017 PDAM Kabupaten Ogan Komering Ulu belum mampu menghasilkan laba dan selalu mengalami kerugian, hal ini menyebabkan hasil analisis rasio profitabilitas melalui perhitungan net profit margin, return on investmeny, dan return on equity memperoleh nilai negatif. Hal ini karena perusahaan belum mampu mengelola sumber dana yang dimilikinya secara efisien dan efektif. Sehingga kondisi keuangan PDAM Kabupaten Ogan Komering Ulu tahun 2014 - 2017 dalam kondisi yang tidak baik.

\section{Daftar Pustaka}

Fahmi, Irham. 2014. Analisa Kinerja Keuangan. Alfabeta. Bandung.

Firdaus, Zamzam Fakhry, 2018 Aplikasi Metodologi, Yogyakarta, Penerbit Deepublish

Harahap, Masnuripa. 2018. Analisis Rasio Likuiditas Sebagai Alat Penilaian Untuk Mengukur Kineja Keuangan pada PT Prodia Widyahusada Tbk. Universitas Islam Negeri Sumatera Selatan. Medan.

Kasmir. 2012. Analisis Laporan Keuangan. PT Raja Grafindo Persada. Jakarta.

Kasmir. 2014. Analisis Laporan Keuangan. Cetakan Ketujuh. PT Raja Grafindo Persada. Jakarta.

Munawir. 2010. Analisa Laporan Keuangan. Liberty. Yogyakarta.

Periansya. 2015. Analisa Laporan Keuangan. Politeknik Negeri Sriwijaya. Palembang.

Rudianto. 2013. Akuntansi Manajemen. Erlangga. Jakarta.

Subramanyam. 2010. Analisis Laporan Keuangan. Salemba Empat. Jakarta.

Sugiyono. 2013. Metode Penelitian Kuantitatif, Kualitatif dan R\&D. $C V$ Alfabeta. Bandung.

Wilanda, Rayun. 2017. Analisis Rasio Aktivitas dan Rasio Profitabilitas Terhadap Kinerja Keuangan pada CV Tehnik Putra Perkasa di Baturaja. Program Studi Manajemen STIE Dwi Sakti Baturaja. 